Original Article

\title{
Microbiological characteristics of bloodstream infections in a reference hospital in northeastern Brazil
}

\author{
Características microbiológicas de infecções da corrente sanguínea em hospital de \\ referência no nordeste do Brasil.
}



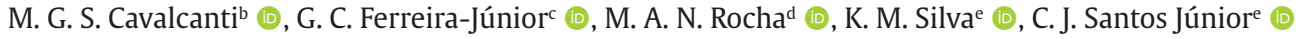 \\ and T. J. M. Rochaa,e (i) \\ ${ }^{a}$ Centro Universitário Cesmac, Maceió, AL, Brasil \\ bUniversidade Federal da Paraíba - UFPB, João Pessoa, PB, Brasil \\ Instituto Federal de Educação, Ciência e Tecnologia do Acre - IFAC, Xapuri, AC, Brasil \\ dUniversidade Estadual de Alagoas - UNEAL, Arapiraca, AL, Brasil \\ eUniversidade Estadual de Ciências da Saúde de Alagoas - UNCISAL, Maceió, AL, Brasil
}

\begin{abstract}
Routine blood culture is used for the detection of bloodstream infections by aerobic and anaerobic bacteria and by common pathogenic yeasts. A retrospective study was conducted in a public hospital in Maceió-AL, by collecting data of all medical records with positive blood cultures. Out of the 2,107 blood cultures performed, $17 \%$ were positive with Staphylococcus coagulase negative (51.14\%), followed by Staphylococcus aureus (11.21\%) and Klebsiella pneumoniae (6.32\%). Gram-positive bacteria predominated among positive blood cultures, highlighting the group of Staphylococcus coagulase-negative. While Gram-negative bacteria had a higher number of species among positive blood cultures.
\end{abstract}

Keywords: hemoculture, blood infection, bacterial resistance.

\begin{abstract}
Resumo
A cultura sanguínea de rotina é usada para a detecção de infecções na corrente sanguínea por bactérias aeróbias e anaeróbias e por leveduras patogênicas comuns. Estudo retrospectivo realizado em hospital público de Maceió-AL, por meio da coleta de dados de todos os prontuários com culturas sanguíneas positivas. Das 2.107 culturas sanguíneas realizadas, $17 \%$ foram positivas com Staphylococcus coagulase negativo (51,14\%), seguido por Staphylococcus aureus $(11,21 \%)$ e Klebsiella pneumoniae (6,32\%). As bactérias Gram-positiva predominaram entre as culturas de sangue positivas, destacando-se o grupo das Staphylococcus coagulase-negativo. Enquanto as bactérias Gram-negativas apresentaram um número maior de espécies entre as culturas de sangue positivas.
\end{abstract}

Palavras-chave: hemocultura, infecção sanguínea, resistência bacteriana.

\section{Introduction}

Several people are hospitalized daily and many of them are affected by various diseases. Bloodstream Infections is a serious disease that can quickly lead to death, and without its adequate clinical and laboratory prognosis can hinder an early treatment in the first hours of the disease and in the patient's survival (Shafer et al., 2019).

The identification of bacteria in blood samples determines an important diagnostic resource in infectious diseases. Bloodstream Infections in hospital units most of the times may indicate a critical state of the patients, with high lethality rates, and with an increase in the hospitalization period and high costs per patient (Pliakos et al., 2019).
Sepsis is a syndrome that can be characterized by a set of very serious changes throughout the body caused by an infection. Previously sepsis was known as septicemias or "blood infection". Today, it is better known as a generalized infection. However, this definition is not entirely correct because the infection is not necessarily present in all organs. Usually, the diagnosis of infection is established to an organ or system, being enough to cause an inflammatory process in the individual's body, which is called Systemic Inflammatory Response Syndrome (SIRS), when the SIRS has an inflammatory cause, it is referred to as a sepsis (Kaukonen et al., 2015). 
The therapeutic adopted includes the antimicrobial, which will be tweaked according to the site of the initial (primary) infection and in case the site cannot be identified, it will cause greater error in the adopted therapy (Friedrich, 2019). Routine blood culture is used for the detection of Bloodstream Infections by aerobic and anaerobic bacteria and by common pathogenic yeasts. Thus, isolated microorganisms that are potentially pathogenic are identified along with an antibiogram when appropriate. Other tests are required to detect mycobacteria, parasites, viruses and some pathogenic fungi (Rocha et al., 2017). Blood culture is indicated for the following cases: septic syndrome, fever, chills, malaise, hypertension, inadequate perfusion, toxicity, tachycardia, hyperventilation; and also in situations involving: evaluation of severe localized infections, such as pneumonias, urinary infection and meningitis (Goff et al., 2017).

Considering the above, the early treatment of Bloodstream Infections is necessary in the first hours because if not treated, the affected individuals may lead to death or result in severe sequelae. However, the blood culture performed in the first hours of the suspicion of infection becomes the gold standard test at the end of the diagnosis (CLSI, 2016). This study aimed to verify the occurrence of bacteria in blood cultures of patients hospitalized in a public unit and analyze the antimicrobial sensitivity profile.

\section{Methods}

The study was approved by the Research Ethics Committee of the Cesmac University Center, under CAAE: 79722317.0.0000.0039 and number of appear 2.543.704. A descriptive and cross-sectional quantitative study approach was carried out. Based on the gathering of data from medical records of patients in the various sectors of the hospital unit from January to December 2016. The study included all microbiological laboratory results related to blood culture in search for microorganisms during the study period. The excluded were those whose laboratory results that were carried out outside the study period.

The research was conducted in the State General Hospital (HGE) unit in Alagoas. Located at Avenida Siqueira Campos, no 2095, Trapiche da Barra in Maceió. The HGE has 338 beds, of which 41 are Intensive Care Units (ICU). The hospital is separated by areas: red area, intended for critically ill patients; yellow area, for patients under observation; blue area, intended for less severe patients and the green area, intended for hospitalized patients, with a physical area of 15,000 square meters in total (Castro, 2020).

The analysis was performed in the archive of the hospital unit of the HGE, and the following variables were obtained: gender, age (I: Newborn (NB); Group II: 2 months -12 years; Group III: 13-19 years; Group IV: 20-59 years and group V: > 60 years), cases of positive or negative blood cultures, isolated microorganisms diagnosed (bacteria and fungi), verifying the main clinic condition found in the sepsis of hospitalized patients. The data was stored in a database using spreadsheets from the Microsoft Office Excel software ${ }^{\circledR} 2010$. The database was updated according to acquisition of data that after being input were checked and corrected.

\section{Results and Discussion}

In total 2,107 blood cultures were performed, of which 348 (17\%) were positive blood cultures. Regarding gender, out of the 2.107 blood cultures analyzed, 1.297 (61.56\%) samples were from male patients. Regarding the relationship between blood cultures performed and distribution by age group in 2016, a frequency of $3(0.06 \%)$ was observed. in group I, 616 (29.28\%) in group II, 113 (5.36\%) in group III, 708 (33.60\%) in group IV, 667 (31.70\%) in group $\mathrm{V}$, thus totaling the 2,107 blood cultures analyzed. Within microorganisms diagnosed in positive blood cultures, 222 (64\%) were related to Hans Christian Joachim Gram Gram-positive bacteria, 113 (32\%) gram-negative bacteria and 13 (4\%) Fungi. Out of the microorganisms found, the Gram-positive bacteria that stood out were: Staphylococcus coagulase-negative (51.14\%) followed by Staphylococcus aureus (11.21\%). Among gram-negative bacteria: Klebsiella pneumoniae (6.32\%), Pseudomonas aeruginosa (4.60\%), Escherichia coli (4.60\%) and Acinetobacter baumannii (3.45\%). There was also the occurrence of fungi, such as Candida sp. (2.06\%) followed by Candida albicans (0.88\%) (Table 1 ).

Although the percentage of Staphylococcus aureus was lower when compared to Staphylococcus coagulasenegative, it is considered one of the main agents that cause bloodstream infections in Europe, according to the European Center for Disease Control and Prevention. Staphylococci are commonly divided into coagulase-positive staphylococci and coagulase-negative staphylococci, according to the production of the extracellular enzyme coagulase (Lisowska-Łysiak et al., 2021). Staphylococcus coagulasenegative include non-pathogenic or opportunistic bacteria, but have been associated as dangerous pathogens in newborns or immunocompromised patients (Heilmann et al., 2019). Therefore, the high amount of these bacteria observed in this research (Table 1), is worrying.

Yeast species of the genus Candida is considered the fourth cause of sepsis, corresponding to $5 \%-10 \%$ according to the data from the Nosocomial Infection Sueveillance System, being $C$. albicans the most prevalent agent. A study conducted evaluating 41 patients in the intensive care unit showed that $C$. albicans was the most frequent species (59\%), followed by C. tropicalis (15\%) and C. parapsilosis (9\%) (França et al., 2008).

The sectors were evaluated in agreement with the classification established by the health institution, according to the patient's condition when checking in for treatment and/or evolutionary clinical treatment. And for a better approach of the sectors they were divided by categories: risk classification that consists of the most critical care sectors of patients in more severe condition; medical clinic, less severe patients but still requiring specific care; and the traumatology sector with surgical trauma, vascular surgical and postoperative patients in general.

Table 2 describes the wings of the hospital and occurrences of blood cultures performed, as well as the prevalences with its respective positive blood cultures, 
Table 1. Distribution of microorganisms found in positive blood cultures performed in a public hospital in the town of Maceió-AL, 2016.

\begin{tabular}{|c|c|c|c|}
\hline & Microrganism & Values $\mathbf{n}=$ & $\%$ \\
\hline \multirow{4}{*}{ Gram-positive } & Staphylococcus coagulase - & 178 & 51.14 \\
\hline & Staphylococcus aureus & 39 & 11.21 \\
\hline & Enterococcus & 03 & 0.86 \\
\hline & Streptococcus viridans-group & 02 & 0.57 \\
\hline \multirow{19}{*}{ Gram-negative } & Klebsiella pneumoniae & 22 & 6.32 \\
\hline & Pseudomonas aeruginosa & 16 & 4.60 \\
\hline & Escherichia coli & 16 & 4.60 \\
\hline & Acinetobacter baumannii & 12 & 3.45 \\
\hline & Enterobacter gergoviae & 09 & 2.59 \\
\hline & Enterobacter aerogenes & 09 & 2.59 \\
\hline & Acinetobacter lwoffii & 07 & 2.01 \\
\hline & Hafnia alvei & 03 & 0.86 \\
\hline & Klebsiella oxytoca & 03 & 0.86 \\
\hline & Klebsiella ozaenae & 02 & 0.57 \\
\hline & Proteus mirabilis & 03 & 0.86 \\
\hline & Proteus vulgaris & 02 & 0.57 \\
\hline & Proteus peneri & 01 & 0.29 \\
\hline & Citrobacter freudii & 02 & 0.57 \\
\hline & Citrobacter koseri & 01 & 0.29 \\
\hline & Enterobacter cloacae & 01 & 0.29 \\
\hline & Providencia stuartii & 02 & 0.57 \\
\hline & Serratia sp. & 01 & 0.29 \\
\hline & Stenotrophomonas maltophilia & 01 & 0.29 \\
\hline \multirow{4}{*}{ Fungi } & Candida $s p$ & 07 & 2.01 \\
\hline & Candida albicans & 03 & 0.86 \\
\hline & Candida não albicans & 02 & 0.57 \\
\hline & Candida glabrata & 01 & 0.29 \\
\hline Total & & 348 & $100 \%$ \\
\hline
\end{tabular}

differentiating them from negative blood cultures in the various sectors. The risk classification wing presented the highest number of positive blood cultures with $53.74 \%$, followed by wings of the Medical Clinic with $30.17 \%$, and finally the wings where the traumatology sectors predominate with $16.09 \%$.

In these sectors, the number of bacteria resistant to the main antimicrobials used in the hospital was also identified, the main ones being: $S$. coagulase negative resistant to methicillin (MRS), with 76 samples (42.69\%) out of the total 178 samples diagnosed with this species; S. aureus MRS (+) in 11 samples (28.20\%) in 39 samples diagnosed with this species; K. pneumoniae expanded spectrum betalactamase producing (ESBL) $(+)$ in 06 samples and $K$. pneumoniae carbapenemase-producing (KPC) in 05 samples adding up to 11 resistant isolates (50\%) out of the total 22 samples detected for this species; $E$. coli $\operatorname{ESBL}(+)$ in 02 samples (12.5\%) out of 16 samples found; $E$. gergoviae ESBL(+) in 02 samples (22.22\%) out of 09 samples; P. mirabilis ESBL(+) in 02 samples (40\%) out of 05 samples detected; P. aeruginosa AmpC (+) in 02 samples (12.5\%) out of 16 found with this microorganism; and Providence stuartii presented ESBL (+) in 01 samples (50\%) out of only two described.

Hospital infections that become recurrent has one of the main causes the production of enzymes responsible for the resistance of the bacterium against certain antimicrobials. These enzymes are classified according to their action against antibiotics. The presence of carbepenemases in the studied strains denotes a critical panorama both regarding the use of antibiotics, since the therapeutic options become very limited, and the potential for dissemination of enzymes (through plasmids) (Logan and Weinstein, 2017).

The hospital environment provides high proliferation and bacterial resistance, due to the exacerbated use of antibiotics by this population in particular, in which it 
Table 2. Distribution of samples performed, differentiating in positive blood cultures and negative blood cultures by the occurrence among the sectors where the patients were located, during the year 2016, in a public hospital in the town of Maceió-AL, 2016.

\begin{tabular}{|c|c|c|c|c|c|}
\hline \multicolumn{2}{|c|}{ Sectors } & \multirow{2}{*}{$\begin{array}{c}\text { Samples Taken } \\
87\end{array}$} & \multirow{2}{*}{$\begin{array}{c}\begin{array}{c}\text { Positive Blood } \\
\text { Cultures }\end{array} \\
12\end{array}$} & \multirow{2}{*}{$\begin{array}{c}\% \\
13.79\end{array}$} & \multirow{2}{*}{$\begin{array}{c}\begin{array}{c}\text { Contaminated } \\
\text { blood cultures }\end{array} \\
02\end{array}$} \\
\hline Risk and & Yellow Area & & & & \\
\hline $\begin{array}{l}\text { Urgency } \\
\text { Classification }\end{array}$ & Red Area & 274 & 56 & 31.38 & 01 \\
\hline & General ICU & 247 & 35 & 14.17 & 02 \\
\hline & Pediatric ICU & 219 & 52 & 23.74 & - \\
\hline & Stroke Unit & 63 & 13 & 20.63 & - \\
\hline & UDT-Cardiology & 29 & 07 & 24.13 & - \\
\hline & $\begin{array}{l}\text { RPA-Surgical } \\
\text { Center }\end{array}$ & 5 & - & - & - \\
\hline \multirow[t]{7}{*}{ Medical Clinics } & A Wing & 18 & 05 & 27.77 & 01 \\
\hline & E Wing & 74 & 03 & 4.05 & - \\
\hline & $\begin{array}{l}\text { F Wing - } \\
\text { Neurology }\end{array}$ & 199 & 35 & 17.58 & 03 \\
\hline & Blue Wing & 129 & 15 & 11.62 & 02 \\
\hline & CTQ-Burned & 49 & 03 & 6.12 & - \\
\hline & Pediatrics & 361 & 44 & 12.18 & - \\
\hline & Green Wing & - & - & - & - \\
\hline \multirow[t]{5}{*}{$\begin{array}{l}\text { Traumatology } \\
\text { sector }\end{array}$} & $\begin{array}{c}\text { B Wing - Vascular } \\
\text { Surgery }\end{array}$ & 09 & 01 & 11.11 & - \\
\hline & $\begin{array}{l}\text { C Wing - Surgical } \\
\text { Clinic }\end{array}$ & 186 & 40 & 2.15 & - \\
\hline & $\begin{array}{c}\text { D Wing - Surgical } \\
\text { - Medical }\end{array}$ & 127 & 25 & 19.68 & 01 \\
\hline & $\begin{array}{l}\text { G Wing - } \\
\text { Orthopedics }\end{array}$ & 31 & 02 & 6.45 & - \\
\hline & Total & 2.107 & 348 & 16.52 & 12 \\
\hline
\end{tabular}

produces greater efficiency of the defense mechanisms of these microorganisms. Some published studies report that the increased mortality rate from infections caused by $K$. pneumoniae is mainly due to sepsis, septic shock, bloodstream infections, and inadequate antimicrobial therapy (Xu et al., 2017). Thus, knowledge about bacterial resistance, its mechanisms of occurrence and prevention, and control strategies is of great importance (Lerminiaux and Cameron, 2019).

A study conducted to evaluate the frequency of hospital infection among 193 patients in intensive care showed that $17.09 \%$ developed hospital infection by $K$. pneumoniae. Among these, $34.09 \%$ were tracheal lavage; $29.55 \%$ of blood samples; $18.18 \%$ urine samples; $11.36 \%$ central venous catheter tip; $4.55 \%$ surgical wound, and $2.27 \%$ of cervical swab.

The results found in this study corroborate studies developed in other health services in Brazil in which a higher frequency of positive samples of blood cultures by bacteria of the genus Staphylococcus was also observed, especially by coagulase-negative Staphylococcus, in addition to a higher occurrence of infections in sectors that treat patients in a higher state of severity (Perna et al., 2015; Ruschel et al., 2017; Dallacorte et al., 2016; Foletto et al., 2019).

The results show that Gram-positive bacteria predominated among positive blood cultures, highlighting the group of Staphylococcus coagulase-negative. While Gram-negative bacteria had a higher number of species among positive blood cultures.

\section{References}

CASTRO, B., 2020 [viewed 17 February 2020]. Relações públicas do HGE [online]. Available from: http://www.saude.al.gov.br/ hospitais/hospital-geral-do-estado-hge/

CLINICAL AND LABORATORY STANDARDS INSTITUTE - CLSI, 2016. MS100-26: performance standards for antimicrobial susceptibility testing. Approved guideline, M-02 and M-07. Wayne.

DALLACORTE, T.S., INDRAS, D.M., TEIXEIRA, J.J.V., PEDER, L.D. and SILVA, C.M., 2016. Prevalência e perfil de sensibilidade 
antimicrobiana de bactérias isoladas de hemoculturas realizadas em hospitais particulares. Revista do Instituto Adolfo Lutz, vol. 75, pp. 1702.

FOLETTO, V.S., BOTTEGA, A., SERAFIN, M.S., ROSA, T.F., MAINARDI, A., FRANCO, L.N. and HÖRNER, R., 2019. Perfil etiológico e de sensibilidade aos antimicrobianos de hemoculturas isoladas de um hospital universitário. Revista Saúde, vol. 45, no. 3, pp. 1-15.

FRANÇA, J.C.B., RIBEIRO, C.E.L. and QUEIROZ-TELLES, F., 2008. Candidemia em um hospital terciário brasileiro: incidência, frequência das diferentes espécies, fatores de risco e suscetibilidade aos antifúngicos. Revista da Sociedade Brasileira de Medicina Tropical, vol. 41, no. 1, pp. 23-28. http://dx.doi org/10.1590/S0037-86822008000100005. PMid:18368266.

FRIEDRICH, A.W., 2019. Control of hospital acquired infections and antimicrobial resistance in Europe: the way to go. Wiener Medizinische Wochenschrift, vol. 169, suppl. 1, pp. 25-30. http:// dx.doi.org/10.1007/s10354-018-0676-5. PMid:30623278.

GOFF, D.A., KULLAR, R., GOLDSTEIN, E.J.C., GILCHRIST, M., NATHWANI, D., CHENG, A.C., CAIRNS, K.A., ESCANDÓN-VARGAS, K., VILLEGAS, M.V., BRINK, A., VAN DEN BERGH, D. and MENDELSON, M., 2017. A global call from five countries to collaborate in antibiotic stewardship: united we succeed, divided we might fail. The Lancet. Infectious Diseases, vol. 17, no. 2, pp. e56-e63. http:// dx.doi.org/10.1016/S1473-3099(16)30386-3. PMid:27866945.

HEILMANN, C., ZIEBUHR, W. and BECKER, K., 2019. Are coagulasenegative staphylococci virulent? Clinical Microbiology and Infection, vol. 25, no. 9, pp. 1071-1080. http://dx.doi.org/10.1016/j. cmi.2018.11.012. PMid:30502487.

KAUKONEN, K. M., BAILEY, M., PILCHER, D., COOPER, J. and BELLOMO, R., 2015. Systemic Inflammatory Response Syndrome Criteria in Defining Severe Sepsis. N Engl J Med, vol. 372, pp. 1629-1638. 10.1056/NEJMoa1415236.

LERMINIAUX, N.A. and CAMERON, A.D.S., 2019. Horizontal transfer of antibiotic resistance genes in clinical environments. Canadian Journal of Microbiology, vol. 65, no. 1, pp. 34-44. http://dx.doi. org/10.1139/cjm-2018-0275. PMid:30248271.
LISOWSKA-ŁYSIAK, K., LAUTERBACH, R., MIĘDZOBRODZKI, J. and KOSECKA-STROJEK, M., 2021. Epidemiology and pathogenesis of Staphylococcus bloodstream infections in humans: a review. Polish Journal of Microbiology, vol. 70, no. 1, pp. 13-23. http:// dx.doi.org/10.33073/pjm-2021-005. PMid:33815523.

LOGAN, L.K. and WEINSTEIN, R.A., 2017. The epidemiology of carbapenem-resistant enterobacteriaceae: the impact and evolution of a global menace. The Journal of Infectious Diseases, vol. 215, suppl. 1, pp. S28-S36. http://dx.doi.org/10.1093/infdis/ jiw282. PMid:28375512.

PERNA, T.D.G.S., PUIATTI, M.A., PERNA, D.H., PEREIRA, N.M.M., COURI, M.V. and FERREIRA, C.M.D., 2015. Prevalência de infecção hospitalar pela bactéria do gênero Klebsiella em uma Unidade de Terapia Intensiva. Revista da Sociedade Brasileira de Clínica Médica, vol. 13, no. 2, pp. 119-123.

PLIAKOS, E.E., ANDREATOS, N., ZIAKAS, P.D. and MYLONAKIS, E., 2019. The cost-effectiveness of antimicrobial lock solutions for the prevention of central line-associated bloodstream infections. Clinical Infectious Diseases, vol. 68, no. 3, pp. 419-425. http:// dx.doi.org/10.1093/cid/ciy511. PMid:29945237.

ROCHA, J.A., VALLE, F.M., SILVA, N.C.Z., NUNES SILVA, A.S.D., VAZ, S.D.S., ARAÚJO, W.N. and MARTINS, I.S., 2017. Disability adjusted life year (Daly) of central-line bloodstream infection (CLABSI) in a university hospital in a developing country, Brazil. Infection Control and Hospital Epidemiology, vol. 38, no. 5, pp. 606-609. http://dx.doi.org/10.1017/ice.2017.22. PMid:28202087.

RUSCHEL, D.B., RODRIGUES, A.D. and FORMOLO, F., 2017. Perfil de resultados de hemoculturas positivas e fatores associados. RBAC, vol. 49, no. 2, pp. 158-163.

SHAFER, C., ALLISON, J., HOGUE, A. and HUNTINGTON, M., 2019. Infectious Disease: Health Care-Associated Infections. FP Essentials, vol. 476, pp. 30-42. PMid:30615408.

XU, L., SUN, X. and MA, X., 2017. Systematic review and meta-analysis of mortality of patients infected with carbapenem-resistant Klebsiella pneumoniae. Annals of Clinical Microbiology and Antimicrobials, vol. 16, no. 1, pp. 18. http://dx.doi.org/10.1186/ s12941-017-0191-3. PMid:28356109. 